\title{
Role of the Tourism Cluster of Porto de Galinhas in the Local Development
}

\author{
Natália Pelinca Braga', João Policarpo Rodrigues Lima², Maria Fernanda Gatto³
}

\begin{abstract}
This paper proposes to prepare a case study on the role of the tourism cluster of Porto de Galinhas in local development. For such, the analysis on the indicators listed in the database of the Annual Report of Social Information (RAIS) was performed, whose time interval was 15 years comprised between 1994 and 2008, the pair years in the aforementioned period being analyzed. The results show that the impact of tourism cluster is positive, both from economic, as the social point of views, i.e. it entails development both in physical infrastructure and in terms of socio-economic relationships of the resident population. This study reinforces therefore, the argument of the positive influence of a tourism cluster in the region, specifically in case of Porto de Galinhas.
\end{abstract}

Keywords: tourism cluster; porto de galinhas; local development.

'Graduada do Curso de Economia da UFPE, Recife, Brasil. (natypelinca@gmail.com)

2Professor Titular do Depto de Economia da UFPE e Pesquisador do CNPq (jprlima@ufpe.br).

${ }^{3}$ Professora Adjunta do Depto de Economia da UFPE (mariagatto@gmail.com) 


\section{Introduction}

In recent years tourism has emerged as one of the activities with the greatest growth potential worldwide. From the year 1980 the sector has gained greater importance in the world, which is touted as the second most globalized, second only to the financial sector.

In Brazil it was not different; the tourism has each year gaining more notoriety due to the significant revenue increases linked to this sector.With respect to the Northeast, tourism is highlighted by the potentialities for development of sunbeach tourism mostly (SOUZA, 2007).

In particular, in a relatively short space of time, Porto de Galinhas in the Ipojuca municipality, Pernambuco, has benefited from the significant increase in the flow of tourists to the Northeast, currently being considered one of the most popular holiday destinations in the region. The overall flow of tourists in Ipojuca was 70,738 in January 2009, according to the Empresa Pernambucana de Turismo (EMPETUR). This represented a share of $16 \%$ of the total number of tourists in the state.

Studies related to tourism often mention and take into account the existence of clusters, generally defined as geographic concentrations of interconnected companies and institutions in a particular field. These are classified as industrial, agricultural or tourism. They can be created spontaneously or through incentives, i.e. public policies. Clusters generally benefit of reduced costs such as the transaction and transport, leading to a regional development due to the efficiency gains. It is worth noting that these tend to result in increased number of jobs and consequently, the disposable income of the resident population, which may lead or not to a positive impact on standards of life quality of this population.

Given the aforementioned considerations, the aim of this work is to show the tourism cluster of Porto de Galinhas has a positive influence on local development using data from the Annual Report of Social Information - RAIS.

\section{Overview of Tourism in Brazil, the Northeast, Pernambuco and Ipojuca}

The tourism sector in Brazil began to experience significant growth of foreigners inflow in the country from the 1990s due to the economic stabilization occurred in that period.

Between 2000 and 2008, the inflow of foreign tourists in Brazil has experienced fluctuations, but never below 3.5 million tourists. Brazil is prominent among the countries of South America when it comes to tourism, as it has a great diversity in the types of tourist attractions, such as beaches, countryside, mountains, ecotourism and historical cities, which attracts not only domestic tourists as well as International ones.

Although in relative disadvantage in terms of Brazil, the Northeast region is not lost on the Brazilian tourism. This receives $9 \%$ of the total foreign tourists who come to Brazil, having four states as major receivers of tourists: Bahia with $4 \%$, Ceará with $2 \%$, Rio Grande do Norte with $1 \%$ and Pernambuco with $2 \%$ in 2008.

Tourism in the Northeast region differs from other regions by being characterized as "sun and beach". The coastal cities have a proper tourism infrastructure (airports, hotels, lodges, parks, etc.) and the beaches stand out by the natural beauty. There is also the presence of cultural-historical tourism, with cities of colonial architecture (Recife, Olinda, Salvador, among others).

In Pernambuco the most popular tourist destinations are: Recife, Olinda, Ipojuca and Fernando de Noronha. The characteristics of tourism in this region are basically the beaches and the historic centers, the latter exist mainly in Olinda. Recife, Ipojuca and Fernando de Noronha together accounted for $75 \%$ of the global flow of tourists in Pernambuco in January 2009, according to the Empresa Pernambucana de Turismo (EMPETUR).

Known nationally and internationally for its beautiful beaches and elected seven consecutive times the most beautiful beach in Brazil by the readers of "Viagem \& Turismo", Porto de Galinhas stands as obligatory destination for tourists visiting the state of Pernambuco. Thus, tourism is considered one of the major economic factors for the region, with well-developed hotel and gastronomic chains. According to EMPETUR research, tourists who visit Porto de Galinhas do it by way of ride, they are married and aged between 26 and 50 years, with $84.5 \%$ of visitors are attracted by local attractions, i.e. sun and beach (Figure I). Thus, it is clear that this destination is considered both for young and more mature people.

On average, yet according to EMPETUR, the tourist spends $\mathrm{R} \$ 150.88$ a day and stands approximately 5 days in Porto de Galinhas. This equates to an average amount of $R \$ 755.00$ spent by each tourist. These mostly rated as excellent condition the environmental quality of beaches.

Important fact to be noted is that the Ipojuca had in 2008, according to the EMPETUR, a total of 167 lodging facilities (hotels apart./Flats, guesthouses and others) and 13,691 beds. This represented a percentage of $58 \%$ of all hotel establishments of Pernambuco, i.e. more than half of the

ISSN: 07 I8-2724. (http://www.jotmi.org) 
establishments connected to hosting at the State were in Ipojuca. Also noteworthy, Ipojuca had 106 hotels, apart. hotels/Flats, hotels and others in 2002. Hence, one can infer that there was $57 \%$ increase in total hotel establishments between 2002 and 2008, which indicates the great development of the tourism sector in the region in a relatively short time interval.

\section{Approach to tourism cluster}

The study of geographic agglomerations of companies has been increasingly improved since the 1970s, because at this time was when the changes in the competitive environment of organizations began to happen. For Porter (1998), clusters are geographic concentrations of interconnected companies, specialized suppliers, service providers, firms in related industries and other institutions (universities, associations and standardization agencies) that compete but also cooperate (SANTA RITA; Nascimento; Lima, 2007).

It can be seen therefore that the greater the degree of association of these companies the greater their efficiency. For encompassing various branches of activities, members of a cluster can be considered both competitors as collaborators, because they maintain a degree of interdependency and at the same time target the same consumer market.

Note that there are market incentives for the formation of clusters due to the gains inherent in them, for example, high yields of scale, positive externalities, agglomeration effects and decreased costs of transportation and communication, as well as the ease of flow information.All these characteristics directly influence the development of the region through the efficiency gains brought by the cluster emergence.
Note that the cluster concept is usually associated with the industry, but it is also applicable to the services sector, particularly related to tourism due to the specific characteristics of the latter, since the "marketed" product is bound to its local base and related companies are geographically close. Overall, a cluster of tourism can be defined as a set of different elements in which are inserted the services provided by companies in the areas of accommodation, catering, travel agency, feeding, and support to parks, the wealth related to tourist vacation, the infrastructure of communication and transportation, natural resources and institutional policies (CUNHA, 2005).

\section{Methodology for identifying clusters}

The methodology adopted in this study for identification of clusters is based on the calculation of the indicator known as the locational quotient (LQ), and two measures of Horizontal Clustering.

To achieve such indexes, the database used to measure the employment in the regions will be the Annual Report of Social Information - RAIS. The years examined are: 1994, 1998, $2000,2002,2004,2006$ and 2008. Years prior to 1994 are not considered due to the need for homogeneity in the classifications of national activities and, until this work completion, the RAIS for the year 2009 has not been disclosed.

Thus, first we need to establish the core of the tourism cluster. However, due to the need for analysis of seven years whose time interval is fifteen, it was necessary to use two existing classifications in the RAIS, i.e. CNAE 95 and CNAE 20. In these two, the names given to activities related to tourism are different, but for greater homoge-
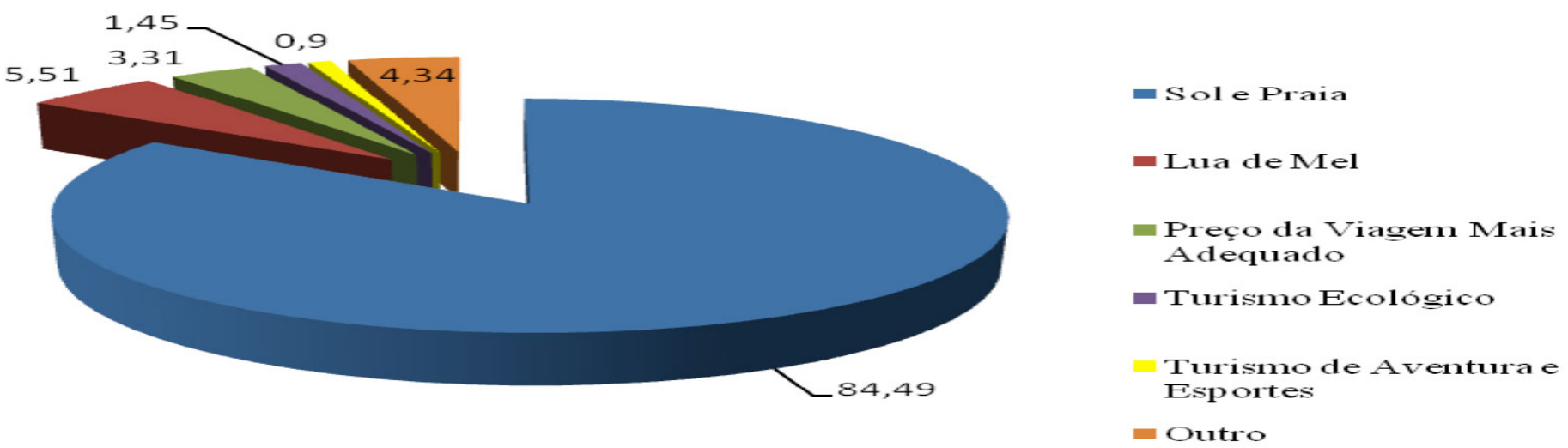

Figure 01: Porto de Galinhas: Determinant factor for the trip of those who came to ride. Source:Authors' calculations data from Secretaria de Turismo do Estado de Pernambuco - EMPETUR

ISSN: 07I 8-2724. (http://www.jotmi.org)

Journal of Technology Management \& Innovation (c) Universidad Alberto Hurtado, Facultad de Economía y Negocios. 
neity, these activities were grouped as follows: food, lodging, road passenger transport, air passenger transport, auxiliary transport activities, travel agencies, car rental and recreational activities.

The clusters identification by the method of locational quotient (LQ) is widely used in studies of economy and regional development, as it allows comparisons between specializations in given sector of selected locations (FINGLENTON, IGLIORI AND MOORE, 2003, apud SOUZA , 2007). QL can be found using the following equation:

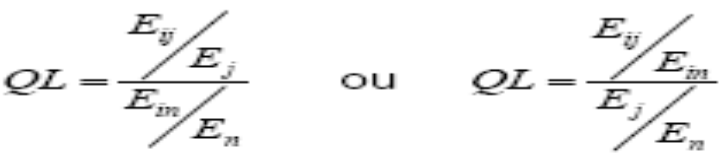

Where:

Eij $=$ Employment of $\mathrm{i}$ sector in the location $\mathrm{j}, \mathrm{Ej}=$ Total employment in location $\mathrm{j}$

Ein $=$ Total employment in the sector $\mathrm{i}$ in the country, region or other territorial dimension in which location $\mathrm{j}$ is inserted. $\mathrm{En}=$ Total employment in the country (in all sectors of the economy)

It is considered that whether LQ is greater than one, there is some degree of specialization of sectors $i$ in location $j$.This is explained because $i$ sector participation was above average participation of the country. If $L Q$ is equal to I, it means that the locations (jen) have the same level of expertise in the sector i. On the other hand, if the LQ is less than I, the level of participation of sector $i$ in total employment is higher in the country than in the city selected.

Through this indicator, one can identify the existence of a potential cluster in a given sector. Although being an indicator frequently used in works of the genre, it is known that the location quotient has some problems in measuring the importance of the cluster in absolute terms. That is, the LQ of a particular location / activity may be high, but in absolute terms irrelevant. To solve the problems in the LQ method, there is an alternative calculation suggested by Fingleton, Igliori and Moore (2003) which measures the excess of the number of jobs in a particular sector in selected location featuring a cluster potential, i.e. how much employed people with occupation representing the location expertise in the sector. To find this amount is necessary to calculate the expected number of jobs for the LQ is equal to I, thus Eij must be replaced by Eij, (expected number of employees in sector $i$ in location $j$ for the $L Q$ equals one) leaving the equation as follows:

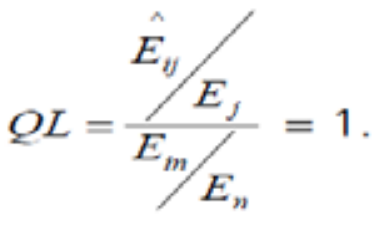

Thus, once defined the number of employees indicating that localities have the same level of expertise in the sector $\mathrm{i}$, we can calculate the number of surplus jobs. The authors Flingleton, Igliori and Moore (2003) called this measure Horizontal Clustering $(\mathrm{HC} *)$. The $\mathrm{HC} *$ is found as follows.

A final way to identify a cluster, still according to the authors cited above, includes information about the geographic proximity of the activity. This measure of Horizontal Clustering is used due to the advantages related to clusters are highly related to the geographical proximity between the agents. The calculation of the cluster intensity:

$$
H C^{*}=E_{i j}-\hat{E}_{i j} \text {. }
$$

Where Eij is the total number of people employed in tourism and $A$ is the area of $i$ location selected.

\section{Dimension of the tourism cluster in Porto de Galinhas}

During I5 years (1994 to 2008), considering data from RAIS , the Ipojuca greatly developed regarding the formal jobs related to the tourism sector. From a total of 503 jobs in 1994, going up to 4375 in 2008, registering a percentage change of 770\% (Table 0I).

It is important to note that in the period, the Ipojuca presented the highest growth rate in the number of formal jobs related to tourism compared to Recife, Pernambuco and the Northeast. Moreover, while the Northeast, Recife and Pernambuco were getting dropped or not on the evolution of the number of employees working on the tourism sector in between 2004 and 2006, Ipojuca grew by $28 \%$. Thus, it becomes apparent the importance of tourism to Ipojuca municipality since, as can be seen in Table $0 \mathrm{I}$, approximately $18 \%$ of total formal employment in the region were related to tourism sector in 2008. This value is very high when comparing this indicator to those of others localities with $7 \%$ Recife, Pernambuco at $6 \%$ and the Northeast with $6 \%$.

Through participation percentage of tourism in the economy can reach the locational quotient (LQ), which demonstrates how the sector is equivalent to the weight of national or regional tourism in a given location. Finding a LQ greater than $I$ is one of the conditions sufficient for the location being considered carrier of a potential cluster. In this sense,

ISSN: 07 I8-2724. (http://www.jotmi.org) 


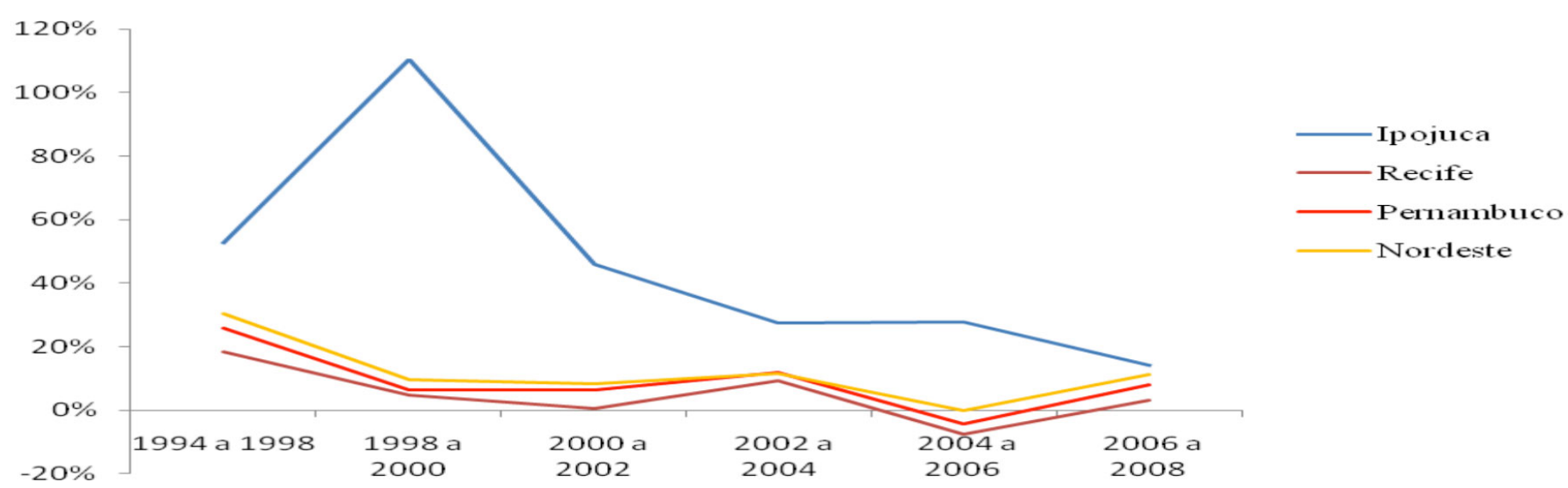

Figure 02: Growth (\%) in the number of people employed in the tourism sector: Northeast, Pernambuco, Recife and Ipojuca. Source: Own elaboration, data from the Annual Report of Social Information - RAIS

the QL's indices were calculated for Ipojuca and places like Recife, Pernambuco and the Northeast, the latter for comparison purposes (Table 02). However, it is noteworthy that the latter QL will be calculated in relation to Brazil, while the first is in relation to the Northeast.

According to the LQ, all locations examined except the Northeast now have potential clusters of tourism from 1998. In 2000, the LQ of Ipojuca had significant increase, from 1.21 to $2.6 \mathrm{I}$, representing high degree of specialization in tourism. Note that in other locations such fact did not happen. This means that the economic importance of the tourism sector is about 3 times greater in the region comprising the Complex of Porto de Galinha than the mean in the Northeast. The other localities have LQ's close to I; in this Ipojuca it increased until reaching the peak in 2006.

The LQ calculation is a very reasonable measure to identify the clusters, but this index shows only the presence or absence of specialization. That is, it does not show the cluster "size" in absolute terms, i.e. the jobs being generated on this function. To solve this problem, other additional indicators are adopted, defined as measures of Horizontal Clustering $(\mathrm{HC})$. One of the measures uses the expected number of employed people (Êij) required for the locality being considered as having cluster. That is, the minimum number of persons needed for LQ equal to I.Thus, once found the Êij one can calculate the $\mathrm{HC}$, which equals to the difference between the actual number of people employed in tourism in a particular locality (Eij) and the expected number (Êij). Measures of Horizontal Clustering confirm the results previously found by the method $L Q$.

According to Table 03 , the surplus of formal tourism employment in the Ipojuca proved to be quite relevant, since from 2000 this figure was nearly I,000 jobs, before 8836 formal employees of the economy, this figure was second only to Recife and Pernambuco. In 2008 the Ipojuca HC* increased to 2914 while in other places this index suffered negative variation. This shows that the tourism sector in Ipojuca is increasingly gaining importance in the economy of the region. Another measure of Horizontal Clustering used to scale the cluster geographically is that measured in terms of the land area of the locality in question. That is, the number of people employed in the tourism sector is divided by land area measured in $\mathrm{km} 2$. This measure is interesting because it attempts to capture the degree of proximity of tourist activities in a given locality. That is, it attempts to capture the degree of proximity between the agents belonging to the cluster, since proximity is an important factor for the cluster concept.

According to Table 04, Recife was the city with the highest concentration of people employed in the tourism sector per $\mathrm{km}^{2}$ during the three years analyzed. In 1998, Recife had the highest HC, followed by Fernando de Noronha and Itamaracá. In 2000, Ipojuca ranked third in terms of concentration of people employed in tourism, totaling HC equal to 3.07 .

It should be noted that from 2000 to 2008 Ipojuca ranked $\mathrm{HC}$ equals to 8.30 , which once again confirms the results obtained previously. Ipojuca had almost 9 formal employees per $\mathrm{km}^{2}$ linked to the tourism sector. The other localities, besides Fernando de Noronha, showed virtually stable and irrelevant $\mathrm{HC}$ during the analysis period.

For these reasons, the indicators used to identify the potential cluster of tourism in Ipojuca indicate the existence; fact ratified every new index calculated. That is, LQ greater than one, $\mathrm{HC}^{*}$ greater than zero and $\mathrm{HC}$ greater than one. All these results were found for Ipojuca. The next step of this work, in Section 6, is to investigate the repercussions of tourism detectable in Porto de Galinhas on the local development.

ISSN: 07I 8-2724. (http://www.jotmi.org) 


\begin{tabular}{|l|l|l|l|l|l|l|l|l|l|l|}
\hline & 1994 & 1998 & 2000 & 2004 & 2008 & & & & & \\
\hline & $\begin{array}{l}\text { People } \\
\text { employed } \\
\text { in tourism }\end{array}$ & $\begin{array}{l}\text { part. } \\
(\%)\end{array}$ & $\begin{array}{l}\text { People } \\
\text { employed } \\
\text { in tourism }\end{array}$ & $\begin{array}{l}\text { part. } \\
(\%)\end{array}$ & $\begin{array}{l}\text { People } \\
\text { employed } \\
\text { in tourism }\end{array}$ & $\begin{array}{l}\text { part. } \\
(\%)\end{array}$ & $\begin{array}{l}\text { People } \\
\text { employed } \\
\text { in tourism }\end{array}$ & $\begin{array}{l}\text { part. } \\
(\%)\end{array}$ & $\begin{array}{l}\text { People } \\
\text { employed } \\
\text { in tourism }\end{array}$ & $\begin{array}{l}\text { part. } \\
(\%)\end{array}$ \\
\hline Ipojuca & 503 & $5 \%$ & 769 & $8 \%$ & 1.619 & $18 \%$ & 3.006 & $20 \%$ & 4.375 & $18 \%$ \\
\hline Recife & 29.762 & $7 \%$ & 35.223 & $9 \%$ & 36.899 & $8 \%$ & 40.583 & $9 \%$ & 38.779 & $7 \%$ \\
\hline Pernambuco & 49.045 & - & 61.669 & $7 \%$ & 65.570 & $7 \%$ & 77.835 & $8 \%$ & 80.416 & $6 \%$ \\
\hline NE & 214.276 & $6 \%$ & 279.469 & $7 \%$ & 306.648 & $7 \%$ & 369.763 & $7 \%$ & 410.920 & $6 \%$ \\
\hline
\end{tabular}

Table 01: Number of formal jobs in the tourism sector and their participation (\%) in relation to total formal jobs: Northeast, Pernambuco, Recife and Ipojuca.

Source: Own elaboration, data from the Annual Report of Social Information - RAIS

\begin{tabular}{|l|l|l|l|r|r|r|r|}
\hline & \multicolumn{1}{|l|}{1994} & \multicolumn{1}{l|}{1998} & \multicolumn{1}{l|}{2000} & \multicolumn{1}{l|}{2002} & \multicolumn{1}{l|}{2004} & \multicolumn{1}{l|}{2006} & \multicolumn{1}{l|}{2008} \\
\hline Ipojuca & 0.80 & 1.21 & 2.61 & 2.45 & 2.94 & 3.16 & 3.00 \\
\hline Recife & 1.23 & 1.27 & 1.16 & 1.24 & 1.30 & 1.24 & 1.14 \\
\hline Pernambuco & 4.10 & 1.09 & 1.06 & 1.08 & 1.11 & 1.07 & 1.04 \\
\hline Northeast & 0.76 & 0.79 & 0.81 & 0.79 & 0.79 & 0.87 & 0.86 \\
\hline
\end{tabular}

Table 02: Locational Quotients (tourism sector) Ipojuca, Recife, Pernambuco and the Northeast Source: Own elaboration, data from the Annual Report of Social Information - RAIS

\begin{tabular}{|c|c|c|c|c|c|c|c|c|c|}
\hline & 1998 & 2000 & 2008 & & & & & & \\
\hline & $\mathrm{E}_{\mathrm{ij}}$ & $\hat{\mathrm{E}}_{\mathrm{ij}}$ & $\begin{array}{l}H C^{*}= \\
\text { Eij - Eij }\end{array}$ & $\mathrm{E}_{\mathrm{ij}}$ & $\hat{E}_{i j}$ & $\begin{array}{l}\mathrm{HC}^{*}=\mathrm{Eij}_{\mathrm{ij}} \\
-\hat{\mathrm{E}}_{\mathrm{ij}}\end{array}$ & $E_{i j}$ & $\hat{\mathrm{E}}_{\mathrm{ij}}$ & $\begin{array}{l}\mathrm{HC}^{*}= \\
\text { Eij - Êij } \\
\end{array}$ \\
\hline $\begin{array}{l}\text { Fernando de } \\
\text { Noronha }\end{array}$ & 104 & 16 & 88 & 179 & 20 & 159 & 473 & 48 & 425 \\
\hline \begin{tabular}{|l} 
llha de \\
Itamaracá
\end{tabular} & 135 & 43 & 92 & 121 & 53 & 68 & 113 & 60 & 53 \\
\hline Ipojuca & 769 & 634 & 135 & 1.619 & 620 & 999 & 4.375 & 1.461 & 2.914 \\
\hline Recife & 35.223 & 27.788 & 7.435 & 36.899 & 31.807 & 5.092 & 38.779 & 34.102 & 4.677 \\
\hline Tamandaré & 62 & 34 & 28 & 99 & 58 & 41 & 207 & 232 & -25 \\
\hline Pernambuco & 61.669 & 56.661 & 5.008 & 65.570 & 61.933 & 3.637 & 80.416 & 77.387 & 3.029 \\
\hline Northeast & 279.469 & 355.558 & \begin{tabular}{|l|}
-76.089 \\
\end{tabular} & 306.648 & 379.918 & -73.270 & 410.920 & 477.902 & -66.982 \\
\hline
\end{tabular}

Table 03: Measurements of Horizontal Clustering $(\mathrm{HC} *)$ : NE, PE and selected locations.Source: Own elaboration, data from the Annual Report of Social Information - RAIS

ISSN: 07 I8-2724. (http://www.jotmi.org)

Journal of Technology Management \& Innovation (c) Universidad Alberto Hurtado, Facultad de Economía y Negocios. 


\begin{tabular}{|c|c|c|c|c|c|c|c|c|c|}
\hline & 1998 & 2000 & 2008 & & & & & & \\
\hline & $\begin{array}{l}\text { People } \\
\text { employed } \\
\text { in tour- } \\
\text { ism* }\end{array}$ & $\mathrm{Km}^{2}$ & $\begin{array}{l}\mathrm{HC}= \\
\mathrm{jobs} / \mathrm{Km}^{2}\end{array}$ & $\begin{array}{l}\text { People } \\
\text { employed } \\
\text { in tour- } \\
\text { ism* }\end{array}$ & $\mathrm{Km}^{2}$ & $\begin{array}{l}\mathrm{HC}= \\
\text { jobs } / \mathrm{Km}^{2}\end{array}$ & $\begin{array}{l}\text { People } \\
\text { employed } \\
\text { in tour- } \\
\text { ism* }\end{array}$ & $\mathrm{Km}^{2}$ & $\begin{array}{l}\mathrm{HC}= \\
\text { jobs } / \mathrm{Km}^{2}\end{array}$ \\
\hline $\begin{array}{l}\text { Fernando de } \\
\text { Noronha }\end{array}$ & 104 & 17 & 6.12 & 179 & 17 & 10.53 & 473 & 17 & 27.82 \\
\hline $\begin{array}{l}\text { llha de } \\
\text { Itamaracá }\end{array}$ & 135 & 65 & 2.08 & $|2|$ & 65 & 1.86 & 113 & 65 & 1.74 \\
\hline Ipojuca & 769 & 527 & 1.46 & 1.619 & 527 & 3.07 & 4.375 & 527 & 8.30 \\
\hline Recife & 35.223 & 271 & 129.97 & 36.899 & 271 & 136.16 & 38.779 & 271 & 143.10 \\
\hline Tamandaré & 62 & 190 & 0.33 & 99 & 190 & 0.52 & 207 & 190 & 1.09 \\
\hline Pernambuco & 61.669 & 98.311 & 0.63 & 65.570 & 98.311 & 0.67 & 80.416 & 98.311 & 0.82 \\
\hline
\end{tabular}

Table 04: Concentration of people employed formally in tourism sector per $\mathrm{km}^{2}(\mathrm{HC})$ - Pernambuco and selected areas. Source: Own elaboration, data from the Annual Report of Social Information - RAIS

* Number of formal employees in the tourism sector

Some relevant impacts of tourism in Porto de Galinhas in the local development

Once characterized the relevance and favorable development of the tourism cluster in Porto de Galinhas, some of its impacts should be analyzed. First, it is interesting to note that from 1991 to 2008 the population in Ipojuca changed from 45,424 to 74,059 , indicating $63 \%$ increase (IBGE data). By comparison, during this same period, Recife had $19 \%$ in demographic expansion. Thus, we note that in the meantime there was a population "boom" in Ipojuca.

During these 18 years, the total number of formal jobs in Ipojuca evolved significantly from 9138 to 24,672 , indicating percentage increase of $170 \%$. Thus, the increase in the total number of formal jobs grew much more than the population in this period, a significantly positive fact. Regarding the tourism, the increase was even more significant, between 1994 and 2008 the number of jobs in this sector increased by $770 \%$, on average of $51 \%$ per year (data from RAIS).

It is now examining whether this dynamic really positively influenced on local development by analyzing the evolution of indicators such as: level of education, average income, number of establishments and number of jobs. The first indicator to be analyzed is the evolution of the educational level of the employed population in Ipojuca (formally). According to data from RAIS, in 1994 approximately $62 \%$ of the population was classified as illiterate and until incomplete 5 th grade, i.e. with only elementary education. We notice that this value denotes that most of the population was inserted at a lowlevel of education. This scenario has changed favorably from the year 2006 , when $60 \%$ of the population had at least com- pleted elementary school (Table 05).

In 2008 there was a significant increase in the educational level of the population formally employed in Ipojuca. That is, $53 \%$ of the population had at least completed the high school. Fact to be noted is that in 2008 and 2006, respectively, $20 \%$ and $21 \%$ of this population had complete undergraduate degree. This situation demonstrates the positive developments in the education of the employed population of the region in a short period of time.

With regard to the education level of the population formally employed in the tourism sector in Ipojuca, $56 \%$ was classified as illiterate or had until the 9th grade incomplete in 1994. However, this scenario has changed in 2000, leaving the majority of the population classified as elementary school level or higher.

In $2004,56 \%$ of the population who formally worked in the tourism sector in Ipojuca had at least incomplete high school. From 2006 this indicator had further positive development, i.e. this year most of the population had completed high school or higher levels. It is worth noting that $6 \%$ of formal employees in the tourism sector and $21 \%$ of formal employees in Ipojuca had completed higher education from 2006 (Table 06), while in Brazil these numbers are respectively $4 \%$ and $15 \%$. Also by way of comparison, the percentage of employees with formal university degree and working directly with tourism is the order of $3 \%$ and $13 \%$ of formal employees in the Northeast.

Once tourism is generally an activity that employs much local labor, this increase in the level of education over the

ISSN: 07 I8-2724. (http://www.jotmi.org) 


\begin{tabular}{|l|l|l|l|l|l|l|l|l|l|l|}
\hline & 1994 & 2000 & 2004 & 2006 & 2008 & & & & & \\
\hline & $\begin{array}{l}\text { Tour- } \\
\text { ism }\end{array}$ & Economy & $\begin{array}{l}\text { Tour- } \\
\text { ism }\end{array}$ & Economy & $\begin{array}{l}\text { Tour- } \\
\text { ism }\end{array}$ & Economy & $\begin{array}{l}\text { Tour- } \\
\text { ism }\end{array}$ & Economy & $\begin{array}{l}\text { Tour- } \\
\text { ism }\end{array}$ & Economy \\
\hline Illiterate & $2 \%$ & $21 \%$ & $1 \%$ & $14 \%$ & $0 \%$ & $10 \%$ & $0 \%$ & $7 \%$ & $0 \%$ & $2 \%$ \\
\hline $\begin{array}{l}\text { Until 5th grade } \\
\text { Incomplete }\end{array}$ & $6 \%$ & $41 \%$ & $5 \%$ & $16 \%$ & $3 \%$ & $27 \%$ & $3 \%$ & $18 \%$ & $3 \%$ & $10 \%$ \\
\hline $\begin{array}{l}\text { Until 5 } 5^{\text {th }} \text { grade } \\
\text { complete }\end{array}$ & $13 \%$ & $12 \%$ & $6 \%$ & $10 \%$ & $3 \%$ & $7 \%$ & $4 \%$ & $6 \%$ & $3 \%$ & $5 \%$ \\
\hline $\begin{array}{l}6^{\text {th }} \text { to 9th grade } \\
\text { Incomplete }\end{array}$ & $35 \%$ & $7 \%$ & $26 \%$ & $16 \%$ & $15 \%$ & $13 \%$ & $11 \%$ & $10 \%$ & $12 \%$ & $10 \%$ \\
\hline $\begin{array}{l}\text { Complete basic } \\
\text { education }\end{array}$ & $21 \%$ & $4 \%$ & $20 \%$ & $8 \%$ & $22 \%$ & $9 \%$ & $16 \%$ & $10 \%$ & $15 \%$ & $12 \%$ \\
\hline $\begin{array}{l}\text { Incomplete high } \\
\text { school }\end{array}$ & $6 \%$ & $2 \%$ & $16 \%$ & $7 \%$ & $16 \%$ & $6 \%$ & $14 \%$ & $6 \%$ & $13 \%$ & $8 \%$ \\
\hline $\begin{array}{l}\text { Complete high } \\
\text { school }\end{array}$ & $13 \%$ & $9 \%$ & $23 \%$ & $21 \%$ & $32 \%$ & $17 \%$ & $42 \%$ & $20 \%$ & $44 \%$ & $30 \%$ \\
\hline $\begin{array}{l}\text { Undergraduate } \\
\text { incomplete }\end{array}$ & $1 \%$ & $1 \%$ & $1 \%$ & $2 \%$ & $3 \%$ & $2 \%$ & $3 \%$ & $3 \%$ & $3 \%$ & $3 \%$ \\
\hline $\begin{array}{l}\text { Undergraduate } \\
\text { complete }\end{array}$ & $2 \%$ & $3 \%$ & $1 \%$ & $5 \%$ & $5 \%$ & $8 \%$ & $6 \%$ & $21 \%$ & $6 \%$ & $20 \%$ \\
\hline $\begin{array}{l}\text { Master of Sci- } \\
\text { ences }\end{array}$ & $1 \%$ & $0 \%$ & $0 \%$ & $0 \%$ & $0 \%$ & $0 \%$ & $0 \%$ & $0 \%$ & $0 \%$ & $0 \%$ \\
\hline Doctorate (PhD) & $0 \%$ & $0 \%$ & $0 \%$ & $0 \%$ & $0 \%$ & $0 \%$ & $0 \%$ & $0 \%$ & $0 \%$ & $0 \%$ \\
\hline TOTAL & 503 & 10.714 & 1.619 & 8.836 & 3.006 & 14.898 & 3.836 & 20.284 & 4.375 & 24.672 \\
\hline
\end{tabular}

Table 05: Percentage share of the number of formal workers in the tourism sector and economy of lpojuca according to education. Source: Own elaboration, data from the Annual Report of Social Information - RAIS

\begin{tabular}{|l|l|l|}
\hline & 2006 & 2008 \\
\hline Ipojuca & $21 \%$ & $20 \%$ \\
\hline Recife & $17 \%$ & $17 \%$ \\
\hline Pernambuco & $13 \%$ & $14 \%$ \\
\hline Northeast & $13 \%$ & $14 \%$ \\
\hline
\end{tabular}

Table 06: Percentage of the population formally employed with complete undergraduate from 2006 to 2008. Northeast, Pernambuco, Recife and Ipojuca. Source: Own elaboration, data from the Annual Report of Social Information - RAIS

years in Ipojuca indicates improved education for the resident population. An interesting fact to be noted is that not only people formally employed in the tourism sector had improved education, but also those formally employed in the other sectors. This fact indicates that there was a general evolution in the city regarding the educational level of the employed population.

The second indicator that will be checked is the evolution of the average earnings of the population of Ipojuca formally employed.The importance of this indicator is linked to possible gain of purchasing power of the working population in the region. Between 1994 and 2008 the income ranges of the population formally employed in Ipojuca do not undergo significant changes. That is, $52 \%$ of the population formally employed had average earnings of up to two minimum wages in 1994 and this percentage changed to $53 \%$ in 2008 . Thus, we note that even there being increased in the total number of formal jobs in lpojuca (130\%), the level of average earnings of the population has not increased significantly.

Reagarding the average earnings for formal employees related to tourism in 2008, most of the population was included in the range of $\mathrm{I} .0 \mathrm{I}$ to $\mathrm{I} .50$ times the minimum wage.

ISSN: 07 I8-2724. (http://www.jotmi.org) 
However, there was a significant increase in the absolute number of people employed in the tourism sector who earn more than 2 minimum wages, i.e. 24 I people in 1994, I,400 in 2008 (Table 07).

As can be observed, the visible change in the previous table was regarding the percentage of formal employees in the economy whose income range was between I.0I and 1.50 minimum wages from $24 \%$ in 1994 to $31 \%$ in 2008 . Concerning to the jobs related to the tourism sector, it was $28 \%$ in 1994 changing to $45 \%$ in 2008 . Thus, it is inferred that in most cases, the increasing the number of formal jobs (both in the tourism sector and in other sectors) in the period analyzed in Ipojuca was mostly incorporated into the aforementioned income range. For comparison, in Recife, Pernambuco and the Northeast the range of average earnings remains virtually the same as in Ipojuca. The two income groups that have the highest concentration of people are from 1.01 to 1.50 and from $2.0 \mathrm{I}$ to 3.0 minimum wages.

Again, it is worth viewing the percentage change in the average income range according to tourism-related jobs in Recife, Pernambuco and the Northeast (Table 08). There is not much difference in the participation of income groups in formal jobs related to tourism, when comparing Ipojuca to the different localities.
Apparently, absolute changes could be verified, but changes in the percentage share of the population in various income groups were not perceived. Thus, it is concluded that the increase in tourism-related labor in Ipojuca was almost completely incorporated into the income range between 1.01 and 1.50 minimum wages, indicating that the jobs offered in the tourism sector generally increase the population's available income, but generate little evolution regarding the income level. That is, people who previously did not have jobs now have it, a quite positive fact, but these jobs offer still reduced wages.

To analyze the evolution of the number of establishments in the region is interesting because it indicates, in a way, the degree of formalization of economic activities. Between 1994 and 2008 there was a significant increase of $493 \%$ in the number of establishments in Ipojuca from I 48 to 878 . The evolution was even greater regarding the number of tourist establishments in the city. This grew $724 \%$ in these 15 years, compared to the $78 \%$ in Recife and $147 \%$ in Pernambuco (Table 09).

The increase in the number of tourist establishments in Ipojuca was $94 \%$ between 1994 and 1998. There was 55\% increase between 1998 and 2000. Importantly, the first time interval mentioned incorporates four years while the second only 2 years. Thus, the value of $55 \%$ becomes significant

\begin{tabular}{|l|l|l|l|l|l|l|l|l|l|l|}
\hline & 1994 & 2000 & 2004 & 2006 & 2008 & & & & & \\
\hline & $\begin{array}{l}\text { Tour- } \\
\text { ism }\end{array}$ & Economy & $\begin{array}{l}\text { Tour- } \\
\text { ism }\end{array}$ & Economy & $\begin{array}{l}\text { Tour- } \\
\text { ism }\end{array}$ & Economy & $\begin{array}{l}\text { Tour- } \\
\text { ism }\end{array}$ & Economy & Tourism & Economy \\
\hline Up 0.5 & $0 \%$ & $0 \%$ & $0 \%$ & $0 \%$ & $0 \%$ & $0 \%$ & $0 \%$ & $0 \%$ & $0 \%$ & $0 \%$ \\
\hline 0.5 I to I & $5 \%$ & $5 \%$ & $3 \%$ & $7 \%$ & $3 \%$ & $10 \%$ & $4 \%$ & $6 \%$ & $4 \%$ & $4 \%$ \\
\hline I.0I.to 1.50 & $28 \%$ & $24 \%$ & $39 \%$ & $25 \%$ & $44 \%$ & $31 \%$ & $45 \%$ & $36 \%$ & $45 \%$ & $31 \%$ \\
\hline I.5I to 2.00 & $19 \%$ & $23 \%$ & $26 \%$ & $16 \%$ & $18 \%$ & $19 \%$ & $17 \%$ & $19 \%$ & $19 \%$ & $18 \%$ \\
\hline 2.01 to 3.00 & $19 \%$ & $18 \%$ & $23 \%$ & $19 \%$ & $17 \%$ & $17 \%$ & $14 \%$ & $16 \%$ & $16 \%$ & $20 \%$ \\
\hline 3.01 to 4.00 & $13 \%$ & $8 \%$ & $4 \%$ & $9 \%$ & $6 \%$ & $8 \%$ & $6 \%$ & $6 \%$ & $6 \%$ & $9 \%$ \\
\hline 4.01 to 5.00 & $6 \%$ & $4 \%$ & $3 \%$ & $6 \%$ & $3 \%$ & $5 \%$ & $3 \%$ & $5 \%$ & $3 \%$ & $5 \%$ \\
\hline 5.01 to 7.00 & $6 \%$ & $5 \%$ & $1 \%$ & $6 \%$ & $4 \%$ & $4 \%$ & $4 \%$ & $4 \%$ & $3 \%$ & $5 \%$ \\
\hline 7.01 to 10.0 & $1 \%$ & $3 \%$ & $1 \%$ & $3 \%$ & $2 \%$ & $2 \%$ & $3 \%$ & $3 \%$ & $3 \%$ & $4 \%$ \\
\hline I0.0I to 15.0 & $1 \%$ & $3 \%$ & $0 \%$ & $3 \%$ & $2 \%$ & $2 \%$ & $1 \%$ & $2 \%$ & $1 \%$ & $2 \%$ \\
\hline I5.0I to 20.0 & $0 \%$ & $2 \%$ & $0 \%$ & $1 \%$ & $1 \%$ & $1 \%$ & $1 \%$ & $1 \%$ & $0 \%$ & $1 \%$ \\
\hline $\begin{array}{l}\text { More than } \\
20.0\end{array}$ & $0 \%$ & $3 \%$ & $0 \%$ & $2 \%$ & $0 \%$ & $1 \%$ & $1 \%$ & $1 \%$ & $0 \%$ & $1 \%$ \\
\hline Ignored & $3 \%$ & $2 \%$ & $0 \%$ & $3 \%$ & $0 \%$ & $0 \%$ & $1 \%$ & $1 \%$ & $0 \%$ & $0 \%$ \\
\hline TOTAL & 503 & 10.714 & 1.619 & 8.836 & 3.006 & 14.898 & 3.836 & 20.284 & 4.375 & 24.672 \\
\hline
\end{tabular}

Table 07: Percentage share of the number of formal workers in the tourism sector and economy of Ipojuca according to average income. Source: Own elaboration, data from the Annual Report of Social Information - RAIS

ISSN: 07 I8-2724. (http://www.jotmi.org)

Journal of Technology Management \& Innovation (c) Universidad Alberto Hurtado, Facultad de Economía y Negocios. 


\begin{tabular}{|l|l|l|l|l|l|l|l|l|l|l|}
\hline & 1994 & 2000 & 2004 & 2006 & 2008 & & & & & \\
\hline & $\begin{array}{l}1.01 \\
\text { to } 1.50\end{array}$ & $\begin{array}{l}2.01 \\
\text { to } 3.0\end{array}$ & $\begin{array}{l}1.01 \\
\text { to } 1.50\end{array}$ & $\begin{array}{l}2.01 \\
\text { to } 3.0\end{array}$ & $\begin{array}{l}1.0 \mathrm{I} \\
\text { to } 1.50\end{array}$ & $\begin{array}{l}2.0 \mathrm{I} \\
\text { to } 3.0\end{array}$ & $\begin{array}{l}\mathrm{I} .0 \mathrm{I} \\
\text { to } 1.50\end{array}$ & $\begin{array}{l}2.0 \mathrm{I} \\
\text { to } 3.0\end{array}$ & $\begin{array}{l}\mathrm{I} .0 \mathrm{I} \\
\text { to } 1.50\end{array}$ & $\begin{array}{l}2.0 \mathrm{I} \\
\text { to } 3.0\end{array}$ \\
\hline Ipojuca & $28 \%$ & $19 \%$ & $39 \%$ & $22 \%$ & $43 \%$ & $17 \%$ & $45 \%$ & $14 \%$ & $45 \%$ & $\mathrm{I} \%$ \\
\hline Recife & $27 \%$ & $17 \%$ & $30 \%$ & $17 \%$ & $47 \%$ & $12 \%$ & $53 \%$ & $9 \%$ & $57 \%$ & $\mathrm{II} \%$ \\
\hline Pernambuco & $25 \%$ & $21 \%$ & $29 \%$ & $21 \%$ & $44 \%$ & $13 \%$ & $52 \%$ & $9 \%$ & $55 \%$ & $12 \%$ \\
\hline Northeast & $23 \%$ & $21 \%$ & $32 \%$ & $19 \%$ & $42 \%$ & $15 \%$ & $49 \%$ & $13 \%$ & $53 \%$ & $13 \%$ \\
\hline
\end{tabular}

Table 08: Percentage of the income participation in the total number of formal jobs related to tourism: Northeast, Pernambuco, Recife and Ipojuca. Source: Own elaboration, data from the Annual Report of Social Information - RAIS

\begin{tabular}{|l|l|l|l|l|l|l|}
\hline & 1994 to 1998 & 1998 to 2000 & 2000 to 2002 & 2002 to 2004 & 2004 to 2006 & 2006 to 2008 \\
\hline Ipojuca & $94 \%$ & $55 \%$ & $61 \%$ & $26 \%$ & $15 \%$ & $18 \%$ \\
\hline Ilha de Itamaracá & $-14 \%$ & $11 \%$ & $10 \%$ & $-35 \%$ & $0 \%$ & $13 \%$ \\
\hline Recife & $45 \%$ & $3 \%$ & $7 \%$ & $12 \%$ & $-2 \%$ & $2 \%$ \\
\hline $\begin{array}{l}\text { Fernando de } \\
\text { Noronha }\end{array}$ & $88 \%$ & $73 \%$ & $75 \%$ & $34 \%$ & $6 \%$ & $-16 \%$ \\
\hline Tamandaré & 0 & $55 \%$ & $24 \%$ & $5 \%$ & $36 \%$ & $33 \%$ \\
\hline Pernambuco & $54 \%$ & $10 \%$ & $14 \%$ & $11 \%$ & $6 \%$ & $8 \%$ \\
\hline Northeast & $68 \%$ & $3 \%$ & $32 \%$ & $12 \%$ & $6 \%$ & $11 \%$ \\
\hline
\end{tabular}

Table 09: Evolution of the number of tourist establishments between 1994 and 2008: Northeast, Pernambuco, Recife and Ipojuca. Source: Own elaboration, data from the Annual Report of Social Information - RAIS

\begin{tabular}{|l|l|l|l|l|l|l|l|l|}
\hline & 1994 & 2000 & 2004 & 2008 & & & & \\
\hline & Tourism & Economy & Tourism & Economy & Tourism & Economy & Tourism & Economy \\
\hline $\begin{array}{l}\text { Fernando de } \\
\text { Noronha }\end{array}$ & 16 & 20 & 52 & 84 & 122 & 176 & 108 & 165 \\
\hline Ipojuca & 34 & 148 & 102 & 338 & 206 & 846 & 280 & 878 \\
\hline $\begin{array}{l}\text { Illha de Itam- } \\
\text { aracá }\end{array}$ & 22 & 61 & 21 & 93 & 15 & 98 & 17 & 114 \\
\hline Tamandaré & 0 & 0 & 17 & 75 & 22 & 105 & 40 & 145 \\
\hline
\end{tabular}

Table 10: Number of establishments in the economy and tourism in major cities related to the sector in Pernambuco (selected cities). Source: Own elaboration, data from the Annual Report of Social Information - RAIS

ISSN: 07 I8-2724. (http://www.jotmi.org)

Journal of Technology Management \& Innovation (C) Universidad Alberto Hurtado, Facultad de Economía y Negocios. 
because the number of establishments increased from 267 to 338 in a short period of time.

It is noteworthy that there was a relatively strong growth of infrastructure associated with this growth in establishments observed in Ipojuca. In a short-time interval there was reform and doubling highway access to the city (still in progress), organization of the city's commercial center and trade in the region, demonstrating that public policies paid more attention at the tourism phenomenon in Porto de Galinhas.

Regarding the number of formal jobs in Ipojuca, as seen in section 5 , there was $130 \%$ increase in total and $770 \%$ in tourism-related jobs; the latter represented absolute increase from 503 jobs in 1994 to 4,375 in 2008. Thus, it is noted that the increased number of establishments was followed by increased number of jobs in the region, which represented both in infrastructure development as gain of purchasing power of the population.

From the above we can observe that the data analyzed here indicate positive impacts of tourism cluster of Porto de Galinhas in terms of a higher level of education, number of establishments, employment and income, infrastructure etc. It is worth noting that tourism also generates informal activities in large numbers attached for example to sightseeing, crafts, street trading, which greatly enhances the impacts analyzed here using only the RAIS database. Checking more fully these effects would require additional effort in research based on primary data, which is out of scope of this paper.

\section{Conclusions}

Given the above, it seems pertinent to confirm the existence of the tourism cluster of Porto de Galinhas and its positive influence on the local development through the analysis of indexes such as level of education, average earnings, number of establishments and number of jobs, data pertaining to RAIS' database.

In the tourism sector was observed concentration of jobs in two activities: hosting and housing. In 2008, the first accounted for $63 \%$, while the second $18 \%$. It is important to remember that these establishments are almost exclusively related to the tourism sector in Porto de Galinhas, which generates less distortion in the analysis.

Some characteristics of the tourism sector in Ipojuca were raised here. It was noticed that between 1998 and 2000 the number of jobs grew by 1 I I\%, showing great development of the sector at this time, a fact endorsed by locational quotient, which was 2.6I. Thus, it was noted that tourism has evolved further since 2000 , where the percentage of people formally employed in the tourism sector grew to $18 \%$ out of the city's total.

By calculating the Horizontal Clustering, it was realized that the tourism cluster of Porto de Galinhas had 2914 surplus jobs in absolute terms in 2008 to a location being considered a potential cluster.

Positive fact related to the region's development was the increased educational level of the population, both those employed in tourism as those employed in other areas. This increase in the education level of the population is not only due to the development of the tourism sector in the region, but this certainly was very important for such a fact actually happened. It is worth noting that this increase occurred in 2000 , a period in which tourism in the region was largely consolidated, thus showing a strong connection between tourism and the increased educational level of the population. It is latent that developments in educational level will generate "fruits" in the long term for the region.

Note that the average income of the population in Ipojuca did not change much over the 15 years analyzed. Most people obtained between I.0 I and I.50 minimum wages, either those formally employed in the tourism sector and in other sectors. However, it is worth remembering that many who had not previously earned this income now have it and thus can increase the level of welfare by increasing consumption. This assertion is justified by the $130 \%$ increase in the number of formal jobs and $770 \%$ increase in formal jobs related to tourism in the period studied here (1994-2008). This suggests that the expansion of tourist activities generated decreased unemployment in the region.

Apparently, one can conclude that the results summarized here, despite the limitations of the database used, indicated that the tourism cluster of Porto de Galinhas positively influenced the local development as the number of people formally employed (in the tourism sector and in other sectors) increased substantially, as well as the number of establishments, alongside improvements in years of education of the employed population. Although we cannot assign these advances only to the tourism sector, it should be noted that this sector has been very relevant to the region development, therefore, being important that public policies reinforce their attention to the tourism sector as a whole and in particular in the case of Porto de Galinhas.

In this respect - public policies - it should be noted that academic studies, such as this one, have pointed to the need to take into account that the structure of tourism at the site has benefited a significant part of the population, as seen above. There are others, however, who call attention to the fact that tourism also caused the displacement of another 
part of the population to outlying areas with shortages of major investments in urbanization, especially sanitation (Silva, 2012). Moreover, public managers and the population need to pay attention to the need to preserve natural resources, mainly vegetables given the tourism expansion. Aside from this, attention must be paid to the economic diversification, thus reducing the idle at low seasons and inserting more permanently the population not benefited from the tourism.

\section{References}

BANCO DO NORDESTE. O Setor Turismo/ Banco do Nordeste. Fortaleza. 2000.93 p. I - Turismo Econômico.

BARROS, A. R. C. Raízes históricas das idéias que subsidiam as políticas de clustering.Revista de Economia Política, São Paulo, v. 22, n. I (85), p. I3 I-I49, 2002.

BRASIL/MTUR/EMBRATUR. Anuários estatísticos, 2005 a 2009. Disponível na internet: http://www.dadosefatos.turismo.gov.br/dadosefatos/anuario/

BRASIL/SETUR/EMPETUR. Sinopse da Pesquisa do Perfil do Turismo Receptivo das Praias de Ipojuca Fevereiro - Maio de 2009. Disponível na internet: http://www2.setur.pe.gov. br/web/setur/ Acesso : 10/11/2009 às 22:14

CUNHA, S. K. e CUNHA, J. C. Clusters de Turismo: abordagem teórica e avaliação. RDE. Revista de Desenvolvimento Econômico, v.VIII, p. 60-67, 2006.

CUNHA, S. K.; CUNHA, J. C. Competitividade e Sustentabilidade de um Cluster de Turismo: uma proposta de modelo sistêmico de medida de impacto do turismo no desenvolvimento local. RAC. Revista deAdministração Contemporânea, Rio de Janeiro, v. v. 9, n. $2^{\mathrm{a}}$ edição, p. I0 I - 124, 2005.

JUNIOR, G. R. e Teixeira, M. Do S. G. Clusters de Serviços: uma oportunidade para o turismo do NE. XXII Encontro Nacional de Engenharia de Produção, Curitiba, 2002.

LEITE, Y.V. P. e Salazar, V. S. O Cluster de Porto de Galinhas. HSM Management Update $n^{\circ}$ 35, 2006.

PORTER, M. E. Cluster and the new economics of competition. Harvard Business School Review, Nov - Dec 1998.

SANTA RITA, L. P. ; Nascimento, T. C. E Lima, M. O. Desenvolvimento regional: um estudo do arranjo produtivo de turismo - Costa dos Corais no Estado de Alagoas. In: Encontro Nacional de Turismo com Base Local, 2007, João Pessoa. X ENTBL, 2007.
SILVA, D. M. da C., Expansão do Espaço Urbano e o Desenvolvimento Local: uma Análise da Atuação do Turismo em Porto de Galinhas -Ipojuca -PE, Dissertação de Mestrado, UFRPE, Pós-graduação em Administração e Desenvolvimento Rural, Recife, 2012.

SOUZA, P. I. de A. Clusters potenciais de turismo na região Nordeste: identificação, características e dimensão econômica.TCC, Recife, 2007.

THOMAZI, S. M. Cluster de Turismo: Introdução ao estudo de arranjo produtivo local. São Paulo. Aleph, 2006. Série Turismo.

TOLEDO, G. L. e Silva, A. C. de A. Estratégias competitivas e cooperativas em clusters turísticos - um diagnóstico da região dos lagos.TCC, São Paulo, 2003.

VASCONCELOS, Y. e Salazar, V. S.. Complexo Porto de Galinhas: um paraíso e uma arena competitiva. Revista Acadêmica - Observatório de Inovação do Turismo, v. II p. I- 19, 2007. 